University of Nebraska - Lincoln

DigitalCommons@University of Nebraska - Lincoln

$12-14-2019$

\title{
ACADEMIC APPLICATION OF SMARTPHONE BY UNIVERSITY STUDENTS IN DEVELOPING COUNTRY
}

Dr. Md. Mostafizur Rahman

Royal University of Dhaka, mm.rahman@royal.edu.bd

Mr. Bashir Ahmed Shakil

Royal University of Dhaka, shakil.bcps@gmail.com

Follow this and additional works at: https://digitalcommons.unl.edu/libphilprac

Rahman, Dr. Md. Mostafizur and Shakil, Mr. Bashir Ahmed, "ACADEMIC APPLICATION OF SMARTPHONE BY UNIVERSITY STUDENTS IN DEVELOPING COUNTRY" (2019). Library Philosophy and Practice (ejournal). 3773.

https://digitalcommons.unl.edu/libphilprac/3773 


\title{
ACADEMIC APPLICATION OF SMARTPHONE BY UNIVERSITY STUDENTS IN DEVELOPING COUNTRY
}

\author{
Dr. Md. Mostafizur Rahman ${ }^{1}$ \\ Associate Professor and Head \\ Department of Library Management and Information Science \\ Royal University of Dhaka, Bangladesh \\ Email: mm.rahman@royal.edu.bd \\ $\&$ \\ Mr. Bashir Ahmed Shakil ${ }^{2}$ \\ Research Student \\ Department of Library Management and Information Science \\ Royal University of Dhaka, Bangladesh \\ Email: shakil.bcps@gmail.com
}

\begin{abstract}
The main premise of this study is to investigate the purposes of academic application of smartphone by university students in developing country and also explores the academic benefits and advantages of using smartphone. The survey method with a structured questionnaire was used for collecting data from 200 students of four private universities in developing country such as Bangladesh. The study findings are - all university students use smartphones and the most popular academic application of smartphone is watching learning videos, followed by reading text books and reading scholarly articles. Then again around $80 \%$ respondent students stated the academic benefits of using smartphone are - easy access to learning materials, skill development and training, save time and increase academic productivity. The study suggests that the smartphone technology enable infrastructure and academic facilities should establish for enhancing the standard of education and improving the quality of research in developing countries.
\end{abstract}

KEYWORD: Academic Application, Academic Use, Smartphone, University Student, Smartphone for Learning, Digital Learning, Education, Higher Education, Developing Country, Bangladesh

\section{INTRODUCTION}

The trendy functional small device smartphone is an integral part of our academic and social life. This sophisticated, vibrant and popular new technology is widely using in the academic activities and influencing the academic performance of the students. This device is running by operating system similar to a computer which offers advanced computing abilities and connectivity options over the telecommunication technology. The smartphone provides reading, writing and editing, messaging, chatting, e-mailing, web browsing, still and video cameras, MP3 player and video playback, calculating, e-marketing, online banking, entertainment, socialization and many more along with voice call. Some smartphones have sophisticated application such as a camera which can work as a scanner (Alfawareh \& Jusoh, 
2014). It is popular among all as this multi-functional tiny device can keep in a pocket of shirt or pant and mobile around the world. Google's study found that due to functionalities the smartphone adoption rate is above 50\% in Australia, United Kingdom, Sweden, Norway, Saudi Arabia and United Arab Emirates and the comScore research released that 4 in every 5 smartphone users, which represents 85.9 million U.S. users, accessed retail content on their mobile device (Rao, 2012).

The smartphone users are increasing rapidly in developing countries. Bangladesh is the fifth largest mobile market in terms of the number of subscribers in Asia Pacific and the ninth largest mobile market in the world (GSMA, 2017). The Bangladesh Telecommunications Regulatory Commission (BTRC) reported in 2019 on its website that the total mobile phone subscribers have reached 159.78 million at the end of March, 2019 in Bangladesh, almost the total population of 165 million. Approximately, 7.5 million units of smartphones were sold in 2018. In 2019, The Bangladesh Mobile Phone Importers Association (BMPIA) reported that 7.69 million units of smartphones were imported in 2018. Newzoo's Global Mobile Market Report (2018) showed that smartphone penetration has increased from 5.2\% in 2017 to $16.1 \%$ in 2018 that means $10.9 \%$ growth a year in developing country Bangladesh.

There is no statistics on smartphone users of the university students in developing countries, whereas the several study reported that the university students are among the highest contributors to the increasing number of smartphone sales in the world. The factor that most influences the increase in smartphone usage is the functionality that helps users in their daily life especially business people and university students (Jacob \& Isaac, 2008). Post (2011) found that $99.8 \%$ of college students in USA have cell phones and its impact is so strong that the college students feel the cell phones are an essential to survive. Whereas Chen and deNoyelles' (2013) findings included: 58\% of the college students in USA used their mobile devices for academic purposes, and freshmen and sophomores tended to use their mobile devices more for educational purposes than upperclassmen. The similar trend is happening in developing countries, thus the purposes of this study is to look into academic application of smartphone, it's benefits and advantages in academic performance of the private university students in developing country like Bangladesh as these students come from well-off family.

\section{OBJECTIVE OF THE STUDY}

The effects of using smartphone in academic performance of the students are very common debating issues in academic arena today. Many scholarly research works are already done in this field. Whereas, a few research works are carried out on academic application of 
smartphone by the university students especially the private university students in developing countries and this is the first initiative to carry out study on the academic application of smartphone by private university students in developing country such as Bangladesh.

The general objective of this study is to investigate the reasons of using smartphone by the university students in developing country. On the other hand, the specific objectives are to explore-

1. The purposes of academic application of smartphone by university students;

2. The perception about the academic benefits and advantages of using smartphone by university students; and

3. The relationship between academic application of smartphone and demographic variables such as age, gender, status and place of origin of the university students.

\section{METHODOLOGY}

This study followed the quantitative method of research. The sites of data collection were four private universities in developing country Bangladesh, namely, BRAC University (BRACU), Daffodil International University (DIU), Royal University of Dhaka (RUD) and University of Information Technology and Science (UITS). The survey method with a structured questionnaire was used for collecting data. A total of 200 questionnaires were distributed among the undergraduate and graduate students of different departments of four private universities from September to December 2018. The duly completed 200 questionnaires were returned from them. The rate of response was 100\%. All the collected data were duly coded after editing for computer input. The statistical software package SPSS version 19 and MS Excel were used to analysis the collected data with the principles of research ethics, validity and reliability.

\section{LITERATURE REVIEW}

Smartphone is an effective and useful device that's influencing the people's lives and socioeconomic activities in the modern world. The researchers carried out many studies on the impact of using smartphone in different fields but this study reviewed the literature of impact of application of smartphone on academic purposes only. The review of the literature revealed that many studies such as - Froese et al. (2012), Indell and Bohlander (2012), Elder (2013), Alfawareh and Jusoh (2014), Rung, Warnke, and Mattheos (2014) have conducted on assessing the use and effects of smartphone especially for learning purposes, and reported that smartphone has negatively effects on learning processes. Whereas, Ifeanyi and 
Chukwuere (2018) deployed a study on 375 undergraduate students using questionnaire to determine the impact of smartphone and found that most undergraduate students are using their smartphones to engage with fellow students and lecturers. It was also found that using smartphone distracts students from their studies in certain aspects but has also the impact of increasing academic capabilities and progression. In another study, Johnson and Radhakrishnan (2016) investigated the academic application of smartphones among the Business Studies undergraduate program students and found that there is a positive perspectives towards academic application of smartphones, and the academic use, advantages, and impact of smartphones have been proved to be positive.

Bradley and Holley (2011) examined mobile phone use for academic learning by undergraduate students at London Metropolitan University and found that students use mobile phones to communicate with classmates, search for information, access learning materials, generate contents, record presentations and take notes. The similar results were found from Kukulska-Hulme et al. (2011), Kim, Ilon, and Altmann (2013) and Cheung (2014) studies. Kukulska-Hulme et al. (2011) explored the application of mobile devices for learning purposes from the learners' perspective on students in master and doctoral programs from Australia, Hong Kong, Portugal, Sweden and UK. The study showed the findings that students in all five countries use mobile phones for learning-related activities like searching for information, reading e-books, listening to education materials, communicating with classmates, group work and collaboration, note taking and scheduling. In another study, Kim, Ilon, and Altmann (2013) found that most of education and engineering university students at one Korean university widely use smartphone to check dictionary, view documents, translate texts, e-mail and text to classmates and teachers, take notes, manage schedules, access media and social networking websites. Whereas, Cheung (2014) reported that the undergraduate students in marketing and public relations at the Hong Kong Polytechnic University use smartphone to perform the following learning activities: sending emails to classmates, reading notes, searching Google Scholar, posting comments and uploading contents to the course website.

Dresselhaus and Shrode (2012) looked at undergraduate and graduate students at one university in USA and found that $43.0 \%$ of study participants use smartphone for academic purposes daily or weekly. On the other hand, Bomhold (2013) conducted a survey among undergraduate students at one university in USA to study the use smartphone for academic purposes and found that use of search engines is very low (10.4\%) among most frequently 
used apps, while a significant number $(75.5 \%)$ of them use the apps to find academic information.

Chen and deNoyelles (2013) explored the potential use and barriers of smartphone by surveying 809 undergraduate and 133 graduate students of University of Central Florida and reported that students need more academic friendly devices such as tablets and additional support to integrate mobile technologies into learning related activities. Whereas, Alfawareh and Jusoh (2014) studied the use of smartphone among 324 university students of Najran University in Saudi Arabia and revealed that 94.4\% students own smartphone and they use smartphone for learning purposes. This study found that $91.7 \%$ students use smartphone to $\log$ on to student portal and $60.9 \%$ never used for Blackboard access.

Dahlstrom, Dziuban, and Walker (2014) deployed a study on a sample of 75,000 university students in USA and reported that students' learning activities with smartphone are mostly related to accessing a course management system for teaching materials, news, grades etc. While Dukic, Chiu, and Lo (2015) conducted a research on LIS postgraduate students from the University of Hong Kong and the University of Tsukuba in Japan and revealed that students rarely use smartphone for reading academic resources. They prefer to use smartphone for learning related activities like discussing assignments, accessing resources and news from the course learning platform, checking course emails, etc.

Hossain and Ahmed (2016) carried out a survey among 316 students of Dhaka University in Bangladesh to explore the use and perceptions of smartphone for accessing academic information and found nearly two-thirds of the respondents utilize smartphone as a means to access academic information. Among them, half of the students use smartphone to record class notes. Students have positive perceptions towards smartphone as a tool for academic use. Although there are some differences in terms of gender, age, place of origin, and duration of use, it is due to the fact that smartphone is new to them.

Atas and Celik (2019) conducted a study among 842 university students studying in 101 different universities in developing countries. The results indicated that the most frequent smartphone use purpose is texting and talking with someone, followed by checking social media and doing Internet search, while the less frequent purpose is shopping. Smartphones are mostly used by university students to spend free time when bored, alone, and/or waiting for someone.

In view of the above, it can be concluded that the smartphone is an important tool of learning and entertainments of the university students. The applications of this new device in academic field are increasing academic capabilities and progression of the students. The 
university students in developing countries have already started using smartphone in academic purposes as they have realized the academic advantages of smartphone.

\section{RESULTS AND DISCUSSION}

This study made survey through questionnaire to collect data for investigating the purposes of academic use of smartphone by the private university students in developing country Bangladesh. The collected data of demographic variables of respondent students, ownership of smartphone, duration of using smartphone, use of smartphone for academic purposes, benefits and advantages of academic use of smartphone were analyzed and measured the relationship between academic use of smartphone and demographic variables of the students by using software SPSS version 19, MS Excel and presented the results in the following tables with discussion.

\section{Demographic Variables of the Students}

A total of 200 students of four private universities such as BRAC University (BRACU), Daffodil International University (DIU), Royal University of Dhaka (RUD) and University of Information Technology and Science (UITS) were participated in this study. Out of 200 students, the questionnaires were distributed among 50 students of each university and all duly filled up questionnaires were got back from them.

Table 1: Demographic Variables of the Students

\begin{tabular}{|c|c|c|c|c|c|}
\hline $\begin{array}{l}\text { Sl. } \\
\text { No. }\end{array}$ & Variable & $\begin{array}{l}\text { Total number of } \\
\text { student }(\mathrm{N})\end{array}$ & $\begin{array}{l}\text { Frequency of } \\
\text { respondent }\end{array}$ & $\begin{array}{c}\text { Percentage } \\
(\%)\end{array}$ & $\begin{array}{l}\text { Cumulative } \\
\text { percentage }(\%)\end{array}$ \\
\hline 1. & $\begin{array}{l}\text { Name of the University } \\
\text { BRACU } \\
\text { DIU } \\
\text { RUD } \\
\text { UITS }\end{array}$ & 200 & $\begin{array}{l}50 \\
50 \\
50 \\
50\end{array}$ & $\begin{array}{l}25.0 \% \\
25.0 \% \\
25.0 \% \\
25.0 \%\end{array}$ & $\begin{array}{c}25.0 \% \\
50.0 \% \\
75.0 \% \\
100.0 \%\end{array}$ \\
\hline 2. & $\begin{array}{l}\text { Age } \\
<20 \text { years } \\
20-25 \text { years } \\
25-30 \text { years } \\
30>\text { years }\end{array}$ & 200 & $\begin{array}{c}39 \\
119 \\
29 \\
13\end{array}$ & $\begin{array}{c}19.5 \% \\
59.5 \% \\
14.5 \% \\
6.5 \% \\
\end{array}$ & $\begin{array}{c}19.5 \% \\
79.0 \% \\
93.5 \% \\
100.0 \%\end{array}$ \\
\hline 3. & $\begin{array}{l}\text { Gender } \\
\text { Male } \\
\text { Female }\end{array}$ & 200 & $\begin{array}{c}154 \\
46\end{array}$ & $\begin{array}{l}77.0 \% \\
23.0 \%\end{array}$ & $\begin{array}{c}77.0 \% \\
100.0 \%\end{array}$ \\
\hline 4. & $\begin{array}{l}\text { Status } \\
\text { Undergraduate } \\
\text { Graduate }\end{array}$ & 200 & $\begin{array}{c}165 \\
35\end{array}$ & $\begin{array}{l}82.5 \% \\
17.5 \%\end{array}$ & $\begin{array}{c}82.5 \% \\
100.0 \%\end{array}$ \\
\hline 5. & $\begin{array}{l}\text { Place of origin } \\
\text { Rural area } \\
\text { Small town } \\
\text { City } \\
\text { Metropolitan city }\end{array}$ & 200 & $\begin{array}{l}33 \\
45 \\
82 \\
40\end{array}$ & $\begin{array}{l}16.5 \% \\
22.5 \% \\
41.0 \% \\
20.0 \% \\
\end{array}$ & $\begin{array}{c}16.5 \% \\
39.0 \% \\
80.0 \% \\
100.0 \% \\
\end{array}$ \\
\hline
\end{tabular}

BRACU: BRAC University, DIU: Daffodil International University, RUD: Royal University of Dhaka, UITS: University of Information Technology and Science 
This study asked the participated students about their demographic variables such as age, gender, status and place of origin and presented the analyzed results in Table 1 . The results show that the largest number of students 119 (59.5\%) was between 20-25 year age, whereas the second largest group 39 (19.5\%) was less than 20 year age, followed by $29(14.5 \%)$ students were between 25-30 year age and the remaining 13 (6.5\%) participants were above 30 year age. However, among the respondents, 154 (77.0\%) was male and 46 (33.0\%) was female students.

Then again, the majority of the respondents 165 (82.5\%) was undergraduate students and the remaining $35(17.5 \%)$ respondents were graduate students. The largest number of respondents $82(41.0 \%)$ came from city area and the second largest group $45(22.5 \%)$ came from small town, followed by $40(20.0 \%)$ students came from metropolitan city and the remaining $33(16.5 \%)$ respondents came from rural area.

\section{Own Smartphone}

This study asked the students "Do you own smartphone?" The all students have given responses which are analyzed and presented the results in Table 2 . The results show that all $200(100.0 \%)$ respondent students owned smartphone. Where, 154 (77.0\%) students were males and the remaining $46(33.0 \%)$ respondents were female students. It means the families of all private university students are capable to bear cost of samrtphone in Bangladesh.

Table 2: Own Smartphone

\begin{tabular}{|c|c|c|c|c|c|c|}
\hline Question & Group & $\begin{array}{c}\text { Response } \\
\mathrm{N}=200\end{array}$ & $\begin{array}{l}\text { Frequency of } \\
\text { respondent }\end{array}$ & $\begin{array}{c}\text { Frequency of owned } \\
\text { smartphone }\end{array}$ & $\begin{array}{c}\text { Percentage } \\
(\%)\end{array}$ & $\begin{array}{c}\text { Cumulative } \\
\text { percentage }(\%)\end{array}$ \\
\hline \multirow{4}{*}{$\begin{array}{l}\text { Do you own } \\
\text { smartphone? }\end{array}$} & \multirow[t]{2}{*}{ Male } & Yes & 154 & \multirow{2}{*}{154} & \multirow{2}{*}{$77.0 \%$} & \multirow[t]{2}{*}{$77.0 \%$} \\
\hline & & No & 00 & & & \\
\hline & \multirow[t]{2}{*}{ Female } & Yes & 46 & \multirow{2}{*}{46} & \multirow{2}{*}{$33.0 \%$} & \multirow[t]{2}{*}{$100.0 \%$} \\
\hline & & No & 00 & & & \\
\hline & & & Total & 200 & $100.0 \%$ & \\
\hline
\end{tabular}

\section{Duration of Using Smartphone}

The participated students were asked "How long have you been using smartphone?" The all students have given responses that are analyzed and shown the results in Table 3.

Table 3: Duration of Using Smartphone

\begin{tabular}{|c|l|c|c|c|}
\hline Question & \multicolumn{1}{|c|}{$\begin{array}{c}\text { Duration of using } \\
\text { smartphone }\end{array}$} & $\begin{array}{c}\text { Frequency of } \\
\text { respondent }\end{array}$ & $\begin{array}{c}\text { Percentage } \\
(\%)\end{array}$ & $\begin{array}{c}\text { Cumulative } \\
\text { percentage }(\%)\end{array}$ \\
\hline \multirow{2}{*}{$\begin{array}{l}\text { How long have you been } \\
\text { using smartphone? }\end{array}$} & Less than 1 year & 3 & $1.5 \%$ & $1.5 \%$ \\
\cline { 2 - 5 } & 1- 2 years & 29 & $14.5 \%$ & $16.0 \%$ \\
\cline { 2 - 5 } & 2-3 years & 32 & $16.0 \%$ & $32.0 \%$ \\
\cline { 2 - 5 } & More than 3 years & 136 & $68.0 \%$ & $100.0 \%$ \\
\hline \multicolumn{2}{|r|}{ Total } & 200 & $100.0 \%$ & \\
\hline
\end{tabular}


The results reveal that the largest group of respondents $136(68.0 \%)$ used smartphone more than 3 years and the second largest group 32 (16.0\%) used smartphone 2-3 years, followed by $29(14.5 \%)$ students used smartphone 1-2 years and the remaining $3(1.5 \%)$ students used smartphone less than 1 year. Which mean the smartphone is very new to the many university students as one-thirds of the students use it less than 3 three years in Bangladesh.

\section{Purpose of Academic Application of Smartphone}

Apart from general use of smartphone like short-message, voice call made and received, this study asked the participated students "How do you apply the smartphone for academic purposes?" along with mentioned seven academic application of smartphone to examine the views whether the students performed these through smartphone or not. The responses of the students were analyzed and shown the results in Table 4. The study results find that the largest number of respondent students 156 (78.0\%) stated, they applied smartphone for watching learning videos whereas $44(22.0 \%)$ students did not watch learning videos on smartphone. The second largest 139 (69.5\%) students applied smartphone for reading text books but 61(30.5\%) did not read text books on it. The third largest group 91 (45.5\%) students applied smartphone for reading scholarly articles whereas 109 (54.5\%) students gave negative response.

Table 4: Purpose of Academic Application of Smartphone

\begin{tabular}{|c|c|c|c|c|}
\hline Question & Academic use of smartphone & $\begin{array}{c}\text { Response } \\
\mathrm{N}=200\end{array}$ & $\begin{array}{c}\text { Frequency of } \\
\text { respondent }\end{array}$ & $\begin{array}{c}\text { Percentage } \\
(\%)\end{array}$ \\
\hline \multirow{14}{*}{$\begin{array}{l}\text { How do you apply the } \\
\text { smartphone for academic } \\
\text { purposes? }\end{array}$} & \multirow[t]{2}{*}{ 1.Watching learning videos } & Yes & 156 & $78.0 \%$ \\
\hline & & No & 44 & $22.0 \%$ \\
\hline & \multirow[t]{2}{*}{ 2. Reading text books } & Yes & 139 & $69.5 \%$ \\
\hline & & No & 61 & $30.5 \%$ \\
\hline & \multirow[t]{2}{*}{ 3. Reading scholarly articles } & Yes & 91 & $45.5 \%$ \\
\hline & & No & 109 & $54.5 \%$ \\
\hline & \multirow[t]{2}{*}{ 4. Recording class notes } & Yes & 68 & $34.0 \%$ \\
\hline & & No & 132 & $66.0 \%$ \\
\hline & \multirow[t]{2}{*}{ 5. Maintaining class routines } & Yes & 55 & $27.5 \%$ \\
\hline & & No & 145 & $72.5 \%$ \\
\hline & \multirow[t]{2}{*}{ 6. Reading reference resources } & Yes & 45 & $22.5 \%$ \\
\hline & & No & 155 & $77.5 \%$ \\
\hline & \multirow[t]{2}{*}{ 7. Other academic purposes } & Yes & 14 & $7.0 \%$ \\
\hline & & No & 186 & $93.0 \%$ \\
\hline
\end{tabular}

After that, $68(34.0 \%)$ students applied smartphone for recording class notes but $132(66.0 \%)$ students did not apply smartphone for recording class notes, followed by 55 (27.5\%) students applied for maintaining class routines whereas 145 (72.5\%) stated negative response and 45 $(22.5 \%)$ students applied for reading reference resources but $155(77.5 \%)$ gave negative 
opinion. The least group 14 (7.0\%) students applied smartphone for other academic purposes whereas 186 (93.0\%) did not apply smartphone for other academic purposes.

These findings indicate that the above two-thirds of the university students applied smartphone for only two purposes, namely, watching learning videos and reading text-books whereas less than half of the university students applied smartphone for the rest five purposes such as reading scholarly articles, recording class notes, maintaining class routines, reading reference resources and other academic purposes. The reason of less academic application of smartphone may be due to lack of skill of operation of smartphone, inadequate smartphone enable infrastructure and academic facilities in the universities. On the other hand, the smarphone is very new to the students in developing country Bangladesh.

\section{Inter-Correlation between Academic Application of Smartphone and Demographic Variables of the Students}

The academic application of smartphone might be influenced by the demographic variables, namely, age, gender, status and place of origin of the respondent students as they came from different backgrounds. This study deployed the Pearson correlation coefficient statistical method to measure the relationship between academic application of smartphone and demographic variables of the respondent students. The results of relationship are shown in Table 5.

The results of the study show that the recording class notes by using smartphone is negative significantly correlated with status $\left(r=-.142^{*}, p<.05\right)$ which means the graduate students do less recording class notes by the smartphone as compare to undergraduate students. Whereas, the maintaining class routines is positive significantly correlated with status $\left(r=.166^{*}, p<.05\right)$, which indicates, the graduate students do maintaining class routines by the smartphone more than undergraduate students. While the reading reference resources is negative significantly correlated with age $\left(r=-.255^{* *}, p<.01\right)$ and status $\left(r=-.351^{* *}, p<.01\right)$, which mean the undergraduate students use smartphone for reading reference resources more as compare to graduate students.

The results also find that there is no significant relationship among any of academic application of smartphone, gender and place of origin of the students. It indicates that the gender and place of origin of the students do not influence the academic application of smartphone.

On the other hand, there is no significant relationship among the higher popular academic application of smartphone such as watching learning videos, reading text books, reading 
scholarly articles and the least academic application of smartphone, namely, other academic purposes and the demographic variables, namely, age, gender, status and place of origin of the respondent students. This is indicated that the demographic variables of the students do not influence the most popular academic application of smartphone in developing country Bangladesh.

Table 5. Inter-Correlation between Academic Application of Smartphone and Demographic Variables of the Students

\begin{tabular}{|c|c|c|c|c|c|c|}
\hline Sl. & \multicolumn{2}{|c|}{ Academic application of smartphone } & Age & Gender & Status & Place of \\
\hline \multirow[t]{3}{*}{1} & \multirow[t]{3}{*}{ Watching learning videos } & Pearson Correlation & -.024 & -.089 & .041 & .082 \\
\hline & & Sig. (2-tailed) & .738 & .208 & .562 & .251 \\
\hline & & $\mathrm{N}$ & 200 & 200 & 200 & 200 \\
\hline \multirow[t]{3}{*}{2} & \multirow[t]{3}{*}{ Reading text books } & Pearson Correlation & -.097 & -.052 & -.019 & -.026 \\
\hline & & Sig. (2-tailed) & .172 & .461 & .786 & .715 \\
\hline & & $\mathrm{N}$ & 200 & 200 & 200 & 200 \\
\hline \multirow[t]{3}{*}{3} & \multirow{3}{*}{$\begin{array}{l}\text { Reading scholarly } \\
\text { articles }\end{array}$} & Pearson Correlation & .030 & -.002 & -.055 & -.065 \\
\hline & & Sig. (2-tailed) & .676 & .981 & .441 & .363 \\
\hline & & $\mathrm{N}$ & 200 & 200 & 200 & 200 \\
\hline \multirow[t]{3}{*}{4} & \multirow[t]{3}{*}{ Recording class notes } & Pearson Correlation & -.090 & -.009 & $-.142^{*}$ & -.012 \\
\hline & & Sig. (2-tailed) & .206 & .899 & .045 & .863 \\
\hline & & $\mathrm{N}$ & 200 & 200 & 200 & 200 \\
\hline \multirow[t]{3}{*}{5} & \multirow{3}{*}{$\begin{array}{l}\text { Maintaining class } \\
\text { routines }\end{array}$} & Pearson Correlation & .137 & .017 & $.166^{*}$ & -.052 \\
\hline & & Sig. (2-tailed) & .054 & .808 & .019 & .467 \\
\hline & & $\mathrm{N}$ & 200 & 200 & 200 & 200 \\
\hline \multirow[t]{3}{*}{6} & \multirow{3}{*}{$\begin{array}{l}\text { Reading reference } \\
\text { resources }\end{array}$} & Pearson Correlation & $-.255^{* *}$ & -.132 & $-.351^{* *}$ & .061 \\
\hline & & Sig. (2-tailed) & .000 & .062 & .000 & .387 \\
\hline & & $\mathrm{N}$ & 200 & 200 & 200 & 200 \\
\hline \multirow[t]{3}{*}{7} & \multirow{3}{*}{$\begin{array}{l}\text { Other academic } \\
\text { purposes }\end{array}$} & Pearson Correlation & -.048 & .057 & -.132 & .121 \\
\hline & & Sig. (2-tailed) & .501 & .424 & .063 & .089 \\
\hline & & $\mathrm{N}$ & 200 & 200 & 200 & 200 \\
\hline
\end{tabular}

**. Correlation is significant at the 0.01 level (2-tailed).

*. Correlation is significant at the 0.05 level (2-tailed).

Whereas, there is negative significant relationship among the lower popular academic application of smartphone, namely, recording class notes and reading reference resources and positive significant relationship between maintaining class routines and status of the students. Then again, the reading reference resources have negative significant relationship with age and status of the students. These findings indicate that the demographic variables such as age and status of the students influence the lower popular academic application of smartphone like recording class notes, maintaining class routines and reading reference resources in developing country Bangladesh.

\section{Benefits of Academic Application of Smartphone}

The respondent students were asked the five questions on benefits of academic application of smartphone to study the views whether they got these benefits from smarphone or not. The 
responded opinions were analyzed and presented the results in Table 6. The results find that the largest number of students $168(84.0 \%)$ stated the smartphone facilitates their learning either in class or outside whereas $32(16.0 \%)$ students stated the negative responses. The second largest number of students $166(83.0 \%)$ said the smartphone helped their skill development and training whereas 34 (17.0\%) students gave the negative responses. The third largest $160(80.0 \%)$ students viewed the smartphone assisted them to find their up-to-date information and $40(20.0 \%)$ students did not get help to find up-to-date information, followed by $159(79.5 \%)$ students reported that the smartphone saved time and increased their productivity whereas $41(20.5 \%)$ did not believe it and $149(74.5 \%)$ students stated that the smartphone helped to minimize faculty-students gaps and $51(25.5 \%)$ students gave the negative responses.

Table 6: Benefits of Academic Application of Smartphone

\begin{tabular}{|c|c|c|c|c|}
\hline $\begin{array}{c}\text { S1. } \\
\text { No. }\end{array}$ & $\begin{array}{c}\text { Question on benefits of academic application of } \\
\text { smartphone }\end{array}$ & $\begin{array}{l}\text { Response } \\
\mathrm{N}=200\end{array}$ & $\begin{array}{c}\text { Frequency of } \\
\text { respondent }\end{array}$ & $\begin{array}{l}\text { Percentage } \\
\quad(\%)\end{array}$ \\
\hline \multirow[t]{2}{*}{1.} & \multirow{2}{*}{$\begin{array}{l}\text { Does smartphone facilitate your learning either in } \\
\text { class or outside? }\end{array}$} & Yes & 168 & $84.0 \%$ \\
\hline & & $\mathrm{No}$ & 32 & $16.0 \%$ \\
\hline \multirow[t]{2}{*}{2.} & \multirow{2}{*}{$\begin{array}{l}\text { Does smartphone help your skill development and } \\
\text { training? }\end{array}$} & Yes & 166 & $83.0 \%$ \\
\hline & & No & 34 & $17.0 \%$ \\
\hline \multirow[t]{2}{*}{3.} & \multirow{2}{*}{$\begin{array}{l}\text { Does smartphone assist to find your up-to-date } \\
\text { information? }\end{array}$} & Yes & 160 & $80.0 \%$ \\
\hline & & No & 40 & $20.0 \%$ \\
\hline \multirow[t]{2}{*}{4.} & \multirow{2}{*}{$\begin{array}{l}\text { Does smartphone save time and increase your } \\
\text { academic productivity? }\end{array}$} & Yes & 159 & $79.5 \%$ \\
\hline & & No & 41 & $20.5 \%$ \\
\hline \multirow[t]{2}{*}{5.} & \multirow{2}{*}{$\begin{array}{l}\text { Does smartphone help to minimize gap between } \\
\text { faculty members and students? }\end{array}$} & Yes & 149 & $74.5 \%$ \\
\hline & & No & 51 & $25.5 \%$ \\
\hline
\end{tabular}

These results indicate that around three-fourths and above of the respondent students got benefits from academic application of smartphone and about one-fourths and less students did not get academic benefits from smartphone in developing country such as Bangladesh.

\section{Advantages of Academic Application of Smartphone}

The participated students were given seven statements on advantages of academic application of smartphone to know the views whether they agree or disagree with the statements on a scale ranging from 7-completely agree, 6-strongly agree, 5-moderately agree, 4-some extend agree, 3-moderately disagree, 2-strongly disagree and 1-completely disagree as shown in Table 7 .The results reveal that the highest mean score on advantage of academic application of smartphone is the impact on overall improvement of academic quality $(\mathrm{M}=5.38, \sigma=1.51)$ and the second highest mean score on advantage for increasing knowledge in field of studies $(\mathrm{M}=5.27, \sigma=1.45)$. 
Whilst the third highest mean score on advantage of academic application of smartphone is the making easier to search relevant information of studies $(M=5.23, \sigma=1.43)$, followed by improving study skills $(\mathrm{M}=5.04, \sigma=1.48)$, making easier to participate in class-related discussions $(\mathrm{M}=4.98, \sigma=1.38)$, increasing motivation towards completing the studies $(M=4.93, \sigma=1.52)$ and the lowest mean score on advantage for making easier to access information and complete the studies $(\mathrm{M}=4.91, \sigma=1.59)$.

Table 7: Advantages of Academic Use of Smartphone

\begin{tabular}{|c|c|c|c|c|}
\hline $\begin{array}{l}\text { Sl. } \\
\text { No. }\end{array}$ & $\begin{array}{l}\text { Statements on advantages of academic use of } \\
\text { smartphone }\end{array}$ & $\begin{array}{c}\text { Mean } \\
\text { Value }(\mathrm{M})\end{array}$ & $\begin{array}{l}\text { Std. Deviation } \\
(\sigma)\end{array}$ & Point Scale \\
\hline 1. & $\begin{array}{l}\text { Smartphone impacts on your overall } \\
\text { improvement of academic quality. }\end{array}$ & 5.38 & 1.51 & \multirow{7}{*}{$\begin{array}{l}\text { 7- Completely agree } \\
\text { 6- Strongly agree } \\
\text { 5- Moderately agree } \\
\text { 4- Some extend agree } \\
\text { 3- Moderately disagree } \\
\text { 2- Strongly disagree } \\
\text { 1- Completely disagree }\end{array}$} \\
\hline 2. & $\begin{array}{l}\text { Smartphone helps to increase knowledge in } \\
\text { your field of studies. }\end{array}$ & 5.27 & 1.45 & \\
\hline 3. & $\begin{array}{l}\text { Smartphone makes easier to search relevant } \\
\text { information of your studies. }\end{array}$ & 5.23 & 1.43 & \\
\hline 4. & Smartphone helps to improve your study skills. & 5.04 & 1.48 & \\
\hline 5. & $\begin{array}{l}\text { Smartphone makes easier to participate in } \\
\text { class-related discussions. }\end{array}$ & 4.98 & 1.38 & \\
\hline 6. & $\begin{array}{l}\text { Smartphone helps to increase motivation } \\
\text { towards completing your studies. }\end{array}$ & 4.93 & 1.52 & \\
\hline 7. & $\begin{array}{l}\text { Smartphone makes easier to access } \\
\text { information and complete your studies. }\end{array}$ & 4.91 & 1.59 & \\
\hline
\end{tabular}

The mean values of all statements are nearly 5 on the highest 7-point scale which indicates that the respondent students are familiar with advantages of academic application of smartphone in developing country Bangladesh.

\section{FINDINGS AND RECOMMENDATIONS}

The application of smartphone can help the students to improve academic performance in many ways. Its benefits are not limited within socialization, communication and dissemination of information. It also has big values in learning, skill development and training, save time and increase academic productivity of the students. That's why the students of developing countries are instigated to engage in smartphone enable academic activities for improvement of their overall academic quality. After the above analysis, the major findings of the study are as follow-

1. All (100\%) male and female students of the participated universities in developing country such as Bangladesh have their own smartphones and more than two-thirds students have been using it more than 3 years. 
2. Above two-thirds of the university students employ smartphone for watching learning videos $(78.0 \%)$ and reading text-books $(69.5 \%)$. Whereas, less than half of the university students utilize smartphone for reading scholarly articles (45.5\%), recording class notes $(34.0 \%)$, maintaining class routines $(27.5 \%)$, reading reference resources $(22.5 \%)$ and other academic purposes $(7.0 \%)$.

3. Around three-fourths and above of the university students find benefits from using smartphone such as access to learning facilities, skill development and training, find up-to-date information, save time, increase academic productivity and minimize faculty-students gaps.

4. The university students believe that the using smartphone extend academic advantages like overall improvement of academic quality, increase knowledge in the field of studies, make easier to search relevant information and improve study skills etc.

5. The gender and place of origin of the students do not influence the academic application of smartphone as there is no significant relationship among any of academic application of smartphone, gender and place of origin of the students.

6. The background variables such as age, gender, status and place of origin of the students do not influence the most popular academic application of smartphone such as watching learning videos, reading text books, reading scholarly articles and the least popular use, namely, other academic purposes.

7. The age and status of the students influence the use of smartphone for recording class notes, maintaining class routines and reading reference resources. Which mean, the undergraduate students utilize smartphone for recording class notes and reading reference resources more as compare to the graduate students. Whereas, the graduate students do maintaining class routines by the smartphone more than the undergraduate students.

The above findings show that the cent-percent of university students use smartphone and most of them utilize its academic benefits and advantages. They use it equally irrespective of background variables such as male and female, rural and urban area. Thus, on the basis of the above findings, this study recommends the following for consideration to policy makers, faculty members and students in developing countries.

1. University authority should introduce smartphone enable modern academic facilities inside and outside of the class as the higher percentage of the students found convenient in participating academic activities through smartphone. 
2. Faculty members should encourage the students to use smartphone in academic purposes and perform academic activities such as live class lectures, post class lectures, notices, opinions, new thoughts, ideas and actively participate in group discussion with peers etc. through social media like facebook, whatsapp, imo, twitter etc.

3. Faculty members should talk with the students about advantages and disadvantages of using smartphone and counsel them how can it makes benefits and distracts academic lives.

4. Students should use smartphone as learning tool, discard unnecessary android software and use effective apps which help to improve academic performance rather than use an entertainment device only.

5. Universities of developing countries should organize training, workshop, seminar on the benefits of using smartphome for academic purposes.

6. Philanthropists should come forward to help the universities in developing countries to implement smartphone enable modern academic infrastructure and facilities for enhancing the quality of higher education and research in the country.

7. Governments of developing countries should make the internet services free for using academic purposes. That's might instigate the authority to implement smartphone enable technology and facilities in the university.

\section{CONCLUSION}

The effective application of smartphone can bring in more advantages than disadvantages to university students' lives. Many previous studies on using smartphone found positive and negative effects on academic performance but several recent studies revealed that the university students of developing countries have started utilizing the academic benefits and advantages of smartphone to help them carry out academic activities rather than use a phone call and entertainment tool. This study found that the university students apply smartphone to improve academic performance, save time, increase productivity, and achieve the quality education. Furthermore, a higher percentage of university students found smartphone convenient to access learning materials, increase knowledge, improve study skill and participate in class discussion. The results of this study will enlighten university students on the effects of using smartphone for multiple academic aspects. It will be highly beneficial if there could be more research carried out in developing countries on how students apply smartphone to increase academic performance, how low-income families or communities 
have impacts on students' usage of smartphone and the impact of smartphone on students attending classes and other academic related activities (Ifeanyi \& Chukwuere, 2018). The results of the study have opened up a new dimension in the field of higher education in developing country Bangladesh and set evidence that a higher percentage of university students are utilizing academic benefits of smartphone to improve academic performance and this trend is increasing rapidly in developing countries including Bangladesh. In light on the above study findings the planners of the developing countries should step forward to establish smartphone technology enable infrastructure and academic facilities in the universities to meet up the ultimate goal of the $21^{\text {st }}$ century's higher education and the beyond.

\section{REFERENCES}

Alfawareh, H. M. \& Jusoh, S. (2014). Smartphones usage among university students: Najran University case. International Journal of Academic Research, 6(2): 321-326.

Atas, A. H. \& Celik, B. (2019). Smartphone use of university students: patterns, purposes, and situations. Malaysian Online Journal of Educational Technology, 7(2): 59-70. Retrieved from: http://dx.doi.org/10.17220/mojet.2019.02.004

Bomhold, C. R. (2013). Educational use of smart phone technology: a survey of mobile phone application use by undergraduate university students. Program: Electronic Library and Information Systems, 47(4): 424-436.

Bradley, C. \& Holley, D. (2011). Empirical research into students' mobile phones and their use for learning. International Journal of Mobile and Blended Learning, 3(4): 38-53.

Chen, B. \& deNoyelles, A. (2013). Exploring students' mobile learning practices in higher education. Educause Review. Retrieved from: http://er.educause.edu/articles/2013/10/ exploring-students-mobile-learning-practices-in-higher-education

Cheung, R. (2014). Predicting user intentions for mobile learning in a project-based environment. International Journal of Electronic Commerce Studies, 4(2): 263-280.

Dahlstrom, E., Dziuban, C. \& Walker, J. (2014). ECAR study of undergraduate students and information technology. Louisville, CO.: EDUCAUSE Center for Applied Research. Retrieved from: https://library.educause.edu/ /media/files/library/2014/10/ers1406-pdf.pdf? la=en

Dresselhaus, A. \& Shrode, F. (2012). Mobile technologies and academics: do students use mobile technologies in their academic lives and are librarians ready to meet this challenge. Information Technology \& Libraries, 31(2): 82-101.

Dukic, Z., Chiu, D. K. W. \& Lo, P. (2015). Learning with smartphones: higher education students' experiences and practices. In: G. Needham, \& M. Ally, (Eds). M-Libraries 5: From devices to people. London: Facet Publishing. 
Elder, A. D. (2013). College students' cell phone use, beliefs, and effects on their learning. College Student Journal, 47(4): 585-592.

Froese, A. D. et al. (2012). Effects of classroom cell phone use on expected and actual learning. College Student Journal, 46(2): 323-332.

GSMA (2017). Country overview: Bangladesh. Retrieved from:

https://www.gsmaintelligence.com/

Hossain, M. E. \& Ahmed, S. M. Z. (2016). Academic use of smartphones by university students: a developing country perspective. The Electronic Library, 34(4): 651-665. Retrieved from: http://www.insidepolitics.org/brookingsreports/MobileLearning .pdf

Ifeanyi, I. P. \& Chukwuere, J. E. (2018). The impact of using smartphones on the academic performance of undergraduate students. Knowledge Management \& E-Learning, 10(3): 290308.

Indell, D. R. \& Bohlander, R. W. (2012). The use and abuse of cell phones and text messaging in the classroom: a survey of college students. College Teaching, 60(1): 1-9. Retrieved from: https://doi.org/10.1080/87567555.2011.604802

Jacob, S. M. \& Isaac, B. (2008). The mobile devices and its mobile learning usage analysis. In: IMECS. Proceedings of the International Multiconference of Engineers and Computer Scientists, Hong Kong, Vol. 1, March, 19-21, pp. 782-87. Retrieved from: https://arxiv.org/abs/1410.4375

Johnson, S. \& Radhakrishnan, N. (2016). Academic use of smartphones among students of business schools in UAE: a study. KIIT Journal of Library and Information Management. 4(1): 33-37.

Kim, J., Ilon, L. \& Altmann, J. (2013). Adapting smartphones as learning technology in a Korean university. Journal of Integrated Design and Process Science, 17(1): 5-16.

Kukulska-Hulme, A. et al. (2011). Mature students using mobile devices in life and learning. International Journal of Mobile and Blended Learning, 3(1): 18-52.

Newzoo Global Mobile Market Report. (2018). Light Version. Retrieved from: https://newzoo.com /insights/trend-reports/newzoo-global-mobile-market-report-2018-lightversion/

Post, H. (2011). 99.8\% of college students have cellphones: Ball State Study.

Retrieved from: http://www.huffingtonpost.com/2010/06/28/998-of-college-students-h_n_ 628161.html

Rao, L. (2012). "comScore: 4 out of 5 smartphone owners use device to shop; Amazon is the most popular mobile retailer". TechCrunch. AOL Inc. Retrieved from: https://techcrunch.com/2012/09/19/comscore-4-out-of-5-smartphone-owners-use-device-toshop-amazon-most-popular-mobile-retailer/ 
Rung, A, Warnke, F. \& Mattheos, N. (2014). Investigating the use of smartphones for learning purposes by Australian Dental Students. JMIR Health and Health, 2(2): 201-210. Retrieved from: https://doi.org/10.2196/mhealth.3120

${ }^{1}$ Dr. Md. Mostafizur Rahman is Associate Professor and Head of the Department of Library Management and Information Science, Royal University of Dhaka, Bangladesh. His area of interest is digital learning, content management system, LIS education and open access. He was the Chairman of the Bangladesh Association of Librarians, Information Scientists and Documenatalists (BALID) for three times.

${ }^{2}$ Bashir Ahmed Shakil is a Master's degree student of the Department of Library Management and Information Science, Royal University of Dhaka, Bangladesh. His area of interest is digital device, medical library system and e-learning. He is working in the Bangladesh College of Physicians and Surgeons. 